\title{
Manajemen Peserta Didik di PKBM Berbasis Alam Studi pada Sanggar Anak Alam (SALAM)
}

\author{
Gunarti Ika Pradewi \\ Universitas Negeri Yogyakarta \\ gunartiikapradewi@gmail.com \\ Wiwik Wijayanti \\ Universitas Negeri Yogyakarta \\ wiwikwijayanti@gmail.com \\ Sukowati \\ Universitas Negeri Yogyakarta \\ sukowati@gmail.com
}

\begin{abstract}
This research aims to describe the pupil personnel administration conducted in Sanggar Anak Alam (SALAM). SALAM is a form of Teaching-learning activity centre which is based in nature. The method used in this research was qualitative research. The data were collected through the interview, observation, and documental study. The results of this research are: (1) in the recruitment process of students, SALAM gets many helps from media to promote their service, moreover the accountability of the process and the funding of education which are conducted become the essential thing to obtain parents' trust and make them enrol their children at SALAM. (2) Related to the grouping and guiding: (a) the number of students in each group only consists of about 15 students, (b) the academic and non-academic guiding are based on four pillars of education which consists of food, health, environment, and socialculture, (c) the guiding of interest is conducted through the interest class, (d) there is student guiding through the forum of parents. (3) The evaluation of students can be conducted every time, but the implementation is different for each student. It occurs because the learning method used is research method. Whereas, for the report of students' learning achievement, there are three methods used, they are: students' learning process note based on the research for one semester, students' attitude notein the learning process for one semester, and students' body skill note in the learning process for onesemester.
\end{abstract}

Keywords: Pupil Personel Administration, Guiding, Research Learning Method

\section{Article Info}

Received date: 22 Juli $2019 \quad$ Revised date: 14 Desember $2019 \quad$ Accepted date: 17 Desember 2019

\section{PENDAHULUAN}

Manajemen peserta didik merupakan salah satu bidang garapan dalam manajemen pendidikan. Keberadaan manajemen peserta didik menjadi hal yang penting. Hal ini karena peserta didik merupakan komponen utama dalam pendidikan. Bahkan secara mikro sejatinya pendidikan merupakan hubungan antara peserta didik dengan pendidik dalam usaha pendidikan Coombs (1968) dalam 
(Kristiawan, M., Safitri, D. \& Lestari, 2017, pp. 55-56). Dengan demikian dapat dikatakan inti dari proses pedidikan ialah hubungan antara pendidik dan peserta didik yang selanjutnya dikelola dalam ranah manajemen peserta didik.

Manajemen peserta didik didefinisikan sebagai pengaturan aktivitas yang berkaitan dengan peserta didik mulai mereka masuk hingga keluar dari suatu sekolah atau madrasah (Kristiawan, M., Safitri, D. \& Lestari, 2017, p. 69). Pernyataan tersebut sejalan dengan yang disampaikan oleh (Farikhah, 2015, p. 38) yang mendefinisikan manajemen peserta didik merupakan bagian dari kegiatan manajemen pendidikan yang berhubungan dengan peserta didik mulai peserta didik masuk di suatu lembaga pendidikan hingga lulus. Dari dua pendapat ahli tersebut maka dapat diketahui bahwa manajemen peserta didik berkaitan dengan pengelolaan terhadap peserta didik yang diterima di suatu lebaga pendidikan hingga yang bersangkutan lulus.

Hamiyah, N. \& Jauhar (2015, p. 44) mengemukakan, ruang lingkup manajemen peserta didik meliputi: perencanaan peserta didik, pembinaan peserta didik, pembinaan peserta didik, evaluasi peserta didik, dan mutasi peserta didik. Sementara Farikhah (2015, p. 39) mengemukakan ruang lingkup manajemen peserta didik meliputi: pengelolaan penerimaan peserta didik baru, pengelolaan bimbingan dan penyuluhan, pengelolaan organisasi siswa intra sekolah (OSIS) dan pengelolaan data peserta didik. Dari ruang lingkup yang dikemukakan ahli tersebut, selanjutnyna peneliti mengambil tiga komponen dalam manajemen peserta didik dalam penelitian ini. Komponen tersebut meliputi: penerimaan peserta didik, penempatan dan pembinaan peserta didik dan evaluasi peserta didik.

Seperti kata pepatah, lain ladang lain belalang, lain lubuk lain pula ikannya. Begitulah penerapan manajemen peserta didik pada jenis pendidikan yang berbeda. Penerapan manajemen peserta didik di lembaga pendidikan formal, lebih kaku karena harus mengikuti kaidah peraturan-peraturan yang mengikat penyelenggaraan pendidikan. Sementara di ranah pendidikan non formal pelaksanaanya lebih fleksibel dan dapat dengan mudah disesuaikan dengan kebutuhan masyarakat dan lembaga pendidikan.

Ada banyak bentuk lembaga pendidikan non formal yang ada di Indonesia. Dalam pasal 26 ayat 3 UU sisdiknas dijelaskan pendidikan nonformal meliputi pendidikan kecakapan hidup, pendidikan anak usia dini (PAUD), pendidikan kepemudaan, pendidikan pemberdayaan perempuan, pendidikan keaksaraan, pendidikan keterampilan dan pelatihan kerja, pendidikan kesetaraan, serta pendidikan lain yang ditujukan untuk mengembangkan kemampuan peserta didik. Selanjutnya untuk pendidikan keaksaraan dan pendidikan ketrampilan biasanya oleh masyarakat diselenggarakan melalui PKBM (pasal 26 ayat 4 UU sisdiknas). Pada praktiknya keberadaan PKBM dianggap sebagai lembaga pendidikan alternatif. Pendidikan alternatif ini muncul ditengah ketidakpuasan terhadap pendidikan arus utama yang dirasa kurang bisa memenuhi kebutuhan peserta didik.

Secara umum pendidikan alternatif memiliki karakter, yaitu: pendekatannya bersifat individual, memberi perhatian besar kepada peserta didik, orang tua atau keluarga, dan pendidik serta dikembangkan berdasarkan minat dan pengalaman(Wildensyah, 2016). Dengan demikian dapat dikatakan pendidikan alternatif lebih bisa mengakomodasi minat masing-masing peserta didik yang mungkin berbeda satu sama lain melalui kerjasama dengan orang tua dan keluarga.

Sejalan dengan hal di atas Rahardjo (2018:88-91) menguraikan ada empat karakter utama yang membedakan sekolah alternatif dengan sekolah arus utama, yaitu: pertama aspek filosofis yang mendasari sekolah alternatif dalam menjalankan pendidikanya ialah filosofis humanistik. Hal ini karena 
pendidikan alternatif berusaha membangun manusia yang seutuhnya dalam proses pendidikanya. Kedua, berorientasi kepaa anak. Hal ini memandakan pendidikan alternatif menghargai peserta didik sebagai individu yang sedang tumbuh, sehingga mereka diperlakukan sesuai perkembangan fisik dan psikologisnya. Ketiga, pendekatan holistik dalam proses pembelajaran. Dengan pendekatan holistik, mata pelajaran tidak disampaikan terpisah seperti yang dilakukan oleh sekolah konvensional, akan tetapi disajikan secara tematik selama kurun waktu tertentu. Keempat, terjalin hubungan demokratis antara guru, murid, dan orang tua. Sehingga mereka secara bersama-sama menciptakan pendidikan yang baik dalam satu komunitas. Dari uraian tersebut maka dapat dikatakan bahwa pendidikan alternatif memiliki fokus pada perkembangan indvidu peserta didik dan dijalankan secara demokratis baik antara peserta didik, orang tua dan fasilittor.

Mintz dalam Miarso (2000, pp. 1-3) mengelompokkan pendidikan alternatif dalam 4 jenis, yaitu: pertama sekolah publik pilihan yang dalam bahasa sehari-hari disebut dengan sekolah negeri. Kedua, sekolah untuk siswa bermasalah. Ketiga, sekolah swasta yang termasuk didalamnya ialah pesantren dan sekolah minggu. Keempat, home schooling yang dalam pelaksanaanya melibatkan peran aktif keluarga dalam memberikan pendidikan bagi anak-anaknya. Dari pengelompokan tersebut maka dapat dikatakan bahwa pendidikan alternatif dapat diselenggarakan baik oleh keluarga, masyarakat (swasta) dan pemerintah.

Sesuai dengan uraian sebelumnya, Ismail (2016, p. 100) mengemukakan, salah satu bentuk dari konsep penddikan alternatif ialah home schooling yang merupakan konsep pendidikan yang dilakukan secara mandiri oleh keluarga dimana materi pembelajarannya dipilih sesuai kebutuhan anak-anak. Home schooling ini dapat dilaksanakan secara tunggal oleh sau keluarga dan secara majemuk oleh dua keluarga atau lebih. Dari uraian di atas, maka dapat dikatakan bahwa konsep pendidikan anak yang dilakukan dengan peran serta keluarga dapat dikelompokkan menjadi home schooling.

Sanggar Anak Alam (SALAM) merupakan salah satu jenis PKBM. Sebagai PKBM tentu pendidikan yang diselenggarakan ialah pendidikan non formal sekaligus melibatkan peran aktif orang tua dan keluarga dalam pendidikan anak-anak mereka. Namun demikian warga belajar atau peserta didik di SALAM menyebut tempat belajar mereka sebagai sekolah.

Sebagai sebuah sekolah SALAM tidak memiliki mata pelajaran yang disediakan untuk peserta didik. Sehingga di sana tidak ada jadwal pelajaran. SALAM mengembangkan kurikulum sendiri berbasis riset dengan pola 'Daur Belajar' dengan indikator capaian yang berbeda di setiap tigkatan kelas (Rahardjo, 2018:175-176). Sehingga proses belajar anakanak di salam akan berbeda satu sama lain, tergantung pada tema riset yang mereka lakukan.

Setiap kelas di SALAM menyususn tema riset masing-masing berdasar antara kesepakatan antara murid, orang tua dan fasilitator. Tema yang diambil merupakan tema yang ada di sekitar. Disisi lain dasar belajar di SALAM ialah 'titen' atau niteni dalam proses riset. Siswa-siswi belajar langsung dari apa yang dilihat dan menyimpulkan dari apa yang mereka rasakan (Rahardjo,2018:176). Setelah melakukan riset anak-anak melakukan presentasi. Presentasi tidak dilakukan serentak oleh semua kelas, tetap sesuai dengan kesiapan anak-anak di setiap kelas (Rahardjo,2018:178). Dengan demikian dapat dikatakan dalam melakuka riset anak-anak di SALAM memfokuskan pada lingkungan sekitar. Sehingga apa yang mereka pelajari tidak terlepas dari kehidupan nyata mereka.

Lebih lanjut penelitian yang dilakukan oleh Halimah (2018, p. ii) misalnya, 
menuturkan bahwa, dalam melakukan perencanaan pembelajaran SALAM menggunakan paradigma konstruktivistik, sehinnga perencanaan pembelajaran dilakukan memalui kegiatan analisis minat dan bakat. Selanjutnya pelaksanaan pembelajaran dan evaluasi pembelajaran menggunakan paradigma pedagogi kritis, selain itu metode pembelajaan yang dilakukan ialah metode riset, dan metode diskusi.

Atas dasar keunikan pengelolaan manajemen peserta didik dalam proses pembelajaran di SALAM maka peneliti merasa perlu untuk melakukan eksplorasi yang mendalam. Adapun komponen yang diteliti terkait komponen dalam manajemen peserta didik yaitu: penerimaan peserta didik, penempatan dan pembinaan peserta didik, dan evaluasi peserta didik. Sedangkan tujuan dari penelitian ini ialah memeberikan informasi tentang pengelolalan atau manajemen peserta didik yang dilakukan di sanggar anak alam (SALAM).

\section{METODE PENELITIAN}

Metode yang digunakan dalam penlitian ini ialah penelitian kualitatif studi kasus. Metode ini dipilih karena peneliti ingin lebih mendalami dan mengeksplorasi praktik manajemen peserta didik diSALAM. Informan dalam penelitian ini meliputi pendiri sekolah, kepala sekolah dan fasilitator. Teknik pengumpulan data yang digunakan ialah dengan wawancara, observasi, dan studi dokumen. Data yang diperoleh dari wawancara, selanjutnya peneliti transkip dan dikelompokkan berdasarkan tema-tema yang sesuai. Observasi dilakukan dengan mengamati aktivitas kelas anak-anak. Sedangkan dalam studi dokumen peneliti menelaah dokumen berupa raport siswa untuk mengetahui hasil akhir dari evaluasi terhadap peserta didik.

Teknik analisis data yang digunakan dalam penelitian ini menggunakan model interaktif Miles dan Huberman yang meliputi: pengumpulan data, reduksi data, display data, penarikan kesimpulan dan verfikasi (Sugiyono, 2013:246-253).Sedangkan untuk menetapkan keabsahan data, peneliti menggunakan teknik triangulasi. Triangulasi merupakan teknik mengumpulkan informasi dari beragam individu dan keadaan menggunakan berbagai metode (Maxwell, 2013:128). Triangulasi sumber dilakukan dengan mewawancarai pendiri dan kepala PKBM. Sementara triangluasi metode dilakukan dengan wawancara, observasi dan studi dokumen.

\section{HASIL \\ PENELITIAN \\ DAN \\ PEMBAHASAN}

\section{Penerimaan peserta didik}

Di SALAM penerimaan peserta didik dilakukan sama seperti sekolah pada umumnya sekitar bulan Juni s.d. Juli. Sebelum membuka pendaftaran sekolah tidak melakukan promosi secara khusus, karena sekolah sudah secara tidak langsung dibantu oleh media untuk memasarkanya. Hal tersebut sesuai dengan petikan wawancara dengan Y berikut:

"Penerimaan warga belajar pada umumnya dilakukan sama seperti sekolah pada umumnya sekitar bulan Juni/ Juli",

Mendukung pernyataan Y, WY juga menerangkan: "penerimaan warga belajar biasanya kami di bulan Juni atau Juli".

Setelah pendaftaran, selanjutnya sekolah melakukan seleksi. Tidak ada syarat khusus untuk siswa, karena di sekolah ini yang diseleksi orang tua bukan siswa. Proses seleksi dilakukan dengan wawancara, pihak sekolah memaparkan program dan komponen pembiayaan seperti petikan wawancara dengan Y berikut:

"Sedangkan kalau mekanisme seleksi dilakukan dengan wawancara kepada orang tua, isinya diskusi tentang visi dan misi sekolah, juga diskusi tentang pembiayaan. Hal ini penting karena dari awal orang tua harus memiliki sesepemahaman yang sama,terkait dengan biaya. Saat wawancara 
kami memaparkan semua kebutuhan selama berpendidikan di sini, kemudian jumlah itu akan dibagi dengan jumlah siswa yang diterima".

Disisi lain WY juga menjelasakan:

"Di sini yang diseleksi bukan calon siswanya tetapi orang tuanya. Karena disini orang tua lah yang tetap bertanggung jawab terhadap pendidikan anaknya, jadi dalam seleksi itu ada wawancara kepada orang tua yang isinya diskusi tentang visi dan misi salam dan juga diskusi tentang pembiayaan".

Petikan wawancara di atas menunjukkan sekolah melibatkan orang tua dalam pendidikan anaknya, disisi lain juga menunjukkan akuntabilitas baik dalam hal penyelenggaraan maupun pembiayaan pendidikan.

Berkenaan dengan akuntabilitas sekolah, hasil penelitian dari Solihat dan Solihat, E. \& Sugiharto (2009, p. 135) mengungkapkan bahwa trasparansi dan akuntabilitas pengelolaan pendidikan berpengaruh positif, baik secara simultan maupun parsial, terhadap tingkat partisipasi orangtua murid di SMA Negeri 107 Jakarta. Hal ini menunjukkan dengan mengelola lembaga pendidikan secara transparan adan akuntabel, orang tua dan anak merasa memiliki sekolah sehingga mereka tidak enggan untuk berpartisispasi dengan sega hal yang diprogramkan sekolah. Disisi lain Trihantoyo (2015, p. 95) menyatakan Adanya akuntabilitas kinerja sekolah dapat membantu sekolah, masyarakat, maupun pemerintah untuk mengenali profil dan ketercapaian program sekolah lebih dalam. Dari berbagai pendapat di atas, maka dapat disimpulkan bahwa akuntabilitas sekolah dapat menjadi sarana bagi masyarakat luas untuk mengetahui profil sekolah. Disisi lain dengan adanya akuntabilitas dapat meningkatkan partisipasi orang tua dalam setiap kegiatan yang diadakan sekolah.
Disisi lain, proses seleksi yang melibatkan orang tua calon peserta didik tentu berbeda dengan proses seleksi di sekolah pada umumnya. Dengan orang tua yang diseleksi sekolah hanya menyaratkan kesepemahaman antara orang tua dan sekolah tentang visi, misi, dan pembiayaan sekolah. Berbeda dengan persyaratan di sekolah pada umumnya yaitu, secara umum berkaitan dengan indikatorindikator berikut: usia, kesehatan, prestasi akademik dan persyaratan administratif lainnya (Farikhah, 2015, p. 41). Selain itu untuk seleksi di sekolah pada umumnya melibatkan tes akademik kepada calon siswa (Farikhah, 2015, p. 44). Dengan demikian dapat dikatakan bahwa sekolah pada umumnya menerima siswa berdasarkan kemampuan akademik yang dimiliki siswa sebelum masuk, sedangkan bagi sekolah ini yang paling penting ialah kesamaan persepsi anara pengelola dan orang tua tentang visi, misi, proses pendidikan dan komponen pembiayaan.

Sementara para ahli mengemukakan Saat penerimaan peserta didik, langkah pertamanya adalah melakukan perencanaan yang meliputi: (a) membuat perkiraan, (b) merumuskan tujuan, (c) mengidentifikasi kegiatan untuk mencapai tujuan, (d) seleksi kegiatan yang akan dilakukan, (e) perumusan langkah-langkah (f) penjadwalan kegiatan yang telah dirumuskan, $(\mathrm{g})$ menentukan alokasi dan sumber anggaran (Imron, 2011, p. 22). Sementara Kristiawan, M., Safitri, D. \& Lestari (2017, p. 70) mengungkapakan dalam penerimaan peserta didik harus memperhatikan kebijakan penerimaan peserta didik. Hal tersebut karena kebijakan yang ada juga mempengaruhi kebijakan operasional di sekolah terutama dalam hal jumlah peserta didik yang akan diterima termasuk terkait daya tampung dan kriteria siswa yang akan di terima.

Urian di atas menunjukkan bahwa pada umumnya di sekolah formal dalam melakukan penerimaan peserta didik memeprtimbangkan kebijakan dan perhitugan anggaran pendidikan, 
dan pada praktiknya sekolah-sekolah menunggu instruksi atau petunjuk yang diberikan oleh dinas pendidikan setempat.

Lebih lanjut, Kristiawan, M., Safitri, D. \& Lestari (2017, p. 71) menguraikan ada dua sistem dalam penerimaan peserta didik meliputi sistem promosi dan sistem seleksi. Pada sistem promosi semua peserta didik yang mendaftar di suatu sekolah diterima begitu saja tanpa seleksi. Sementara untuk sistem seleksi ada tiga macam yaitu seleksi berdasarkan nilai UN, seleksi bakat minat dan kemampuan dan tes masuk. Sisitem dan aturan seleksi seperti yang dikemukakan sebelumnya sama sekali tidak ada di SALAM. Dengan melibatkan partisipasi orang tua dalam seleksi penerimaan peserta didik, sejatinya para pengelola ingin menyakinkan orang tua bahwa pendidikan anak-anak mereka adalah tanggung jawab mereka sendiri. Orang tua tidak bisa lepas tangan begitu saja menyerahkan pendidikan anaknya kepada sekolah. Sehingga kedepan dalam proses pembelajaran terjadisinergi diantara peserta didik, orang tua dan fasilitator.

\section{Penempatan dan pembinaan peserta didik}

a. Penempatan peserta didik.

Setelah selesai melakukan penerimaan peserta didik, langkah selanjutnya ialah melakukan penempataan atau pengelompokan peserta didik. Di SALAM setiap jenjang pendidikan hanya memiliki sekitar 15 siswa per kelas, terkecuali untuk PAUD. Untuk lebih jelasnya, pengelompokan siswa di SALAM dapat dilihat pada tabel berikut.

Tabel 1. Rekap jumlah siswa per kelas

\begin{tabular}{|c|c|c|c|c|c|c|c|}
\hline \multirow[t]{2}{*}{ No } & \multirow[t]{2}{*}{ Kls } & \multicolumn{2}{|c|}{ Anak } & \multirow[t]{2}{*}{ Jumlah } & \multicolumn{2}{|c|}{ Guru } & \multirow[t]{2}{*}{ Jumlah } \\
\hline & & Putra & Putri & & Putra & Putri & \\
\hline 1 & KB & 10 & 15 & 25 & 0 & 3 & 3 \\
\hline 2 & TA & 20 & 12 & 32 & 0 & 5 & 5 \\
\hline 3 & Kls 1 & 8 & 9 & 17 & 1 & 2 & 3 \\
\hline 4 & Kls 2 & 12 & 5 & 17 & 1 & 2 & 3 \\
\hline 5 & Kls 3 & 8 & 7 & 15 & 2 & 1 & 3 \\
\hline 6 & Kls 4 & 11 & 4 & 15 & 1 & 2 & 3 \\
\hline 7 & Kls 5 & 8 & 8 & 16 & 1 & 2 & 3 \\
\hline 8 & Kls 6 & 10 & 6 & 16 & 1 & 2 & 3 \\
\hline 9 & Kls 7 & 6 & 6 & 12 & 1 & 2 & 3 \\
\hline 10 & Kls 8 & 8 & 4 & 12 & 1 & 2 & 3 \\
\hline 11 & Kls 9 & 3 & 4 & 7 & 2 & 0 & 2 \\
\hline 12 & Kls 10 & 0 & 6 & 6 & 1 & 1 & 2 \\
\hline 13 & Kls 11 & 4 & 3 & 7 & 2 & 0 & 2 \\
\hline \multicolumn{2}{|c|}{ Jumlah } & 108 & 89 & 197 & 12 & 27 & 39 \\
\hline \multicolumn{2}{|c|}{ Total } & 236 & & & & & \\
\hline
\end{tabular}

Tabel di atas menunjukkan kelompok siswa di sekolah ini, semua berkisar kurang lebih 15 anak kecuali untuk pendidikan Paud. Dalam melakukan pengelompokan, SALAM menggunakan batas untuk masing masing kelas ialah 15 kursi dengan 3 fasilitator yang menyertainya. Hal ini tentu berbeda dengan standar minimum kelas yang ada di sekolah pada umumnya yang berjumlah 28 untuk SD, 32 untuk SMP, dan 36 untuk SMA dengan hanya disertai oleh satu atau dua orang guru saja (Permendikbud No. 22 Tahun 2016). Pada praktiknya di sekolah jumlah tersebut selanjutnya oleh sekolah banyak di lakukan pengelompokan berdasarkan tingkat pengetahuan dan kemampuan akademik siswa. 
Sejalan dengan hal di atas, penelitian yang dilakukan oleh Sulistyaningsih (2017, p. 1) menyatakan bahwa pengelompokan siswa berdasarkan nilai akademik dan pengetahuan, memiliki dampak positif, yaitu terpenuhinya fasilitas belajar dan siswa merasa nyaman dalam mengikut pelajaran. Sementara dampak negatifnya banyak wali murid yang tidak menyetujui dengan pengelompokan berdasarkan pengetahuan siswa. Hasil penelitian tersebut menunjukkan ada pembedaan yang dilakukan oleh sekolah terhadap siswa yang memiliki nilai akademik tinggi dengan yang kurang, sementara orang tua menginginkan agar sekolah tidak membedakan. Dalam konteks SALAM yang hanya menyediakan satu kelas untuk setiap rombel, maka hal ini tidak terjadi. Dengan jumlah siswa yang hanya berkisar 15 orang dan didampingi oleh 3 fasilitator tentu semua anak dapat terfasilitasi dengan baik.

\section{b. Pembinaan akademik dan non akademik}

Pembinaan akademik yang dilakukan SALAM berdasar pada empat prespektif pendidikan yang dikembangkan yaitu: pangan, kesehatan, lingkungan dan sosial-budaya. Empat prespektif tersebut kemudian dibungkus dalam kegiaatn belajar berbasis riset. Metode riset dalam pembelajaran yang dilakukan di SALAM merupakan wujud dari pendekatan holistik dalam pembelajaran. Hal ini karena dengan metode riset dapat mencakup semua mata pelajaran. Di sekolah ini tidak ada pembelajaran sesuai mata pelajaran. Di sini semua pelajaran di sampaikan secara tematik. Hal ini sesuai dengan petikan wawancara yang dilakukan dengan WY berikut:

"Disini anak-anak belajar sesuai tema, tidak ada mata pelajaran secara khusus. Misalnya tema minggu ini anak meneliti tentang ikan, maka aktivitas pemebelajaran anak-anak tentang ikan. Mereka melakukan pengamatan tentang ikan, mengunjungi toko ikan, dari kegiatan tersebut mereka bisa belajar tentang biologi dengan mempelajari jenis ikan, apa makananya, apa warnanya, dan lain sebagainya. Selain itu mereka juga bisa belajar geografi misalnya terkait lokasi toko ikan ada dimana? Di kecamatan mana? Kabupaten mana? Setelah pulang dari pengamatan mereka menggambar ikan yang tadi diamati, otomatis mereka belajar seni."

Petikan wawancara di atas menunjukkan bahwa jauh sebelum pemerintah menggaungkan K13 sekolah ini lebih dahulu menerapkan K13. Hal ini karena pembelajran yang disajikan secara holistik dan tidak membedakan satu mata pelajaran dengan pelajaran lainya.

Selanjutnya, untuk pembinaan akademik kempat prespektif pendidikan yang dicanangkan SALAM saat pengaplikasianya dapat dilihat juga dari empat pilar pendidikan yang dicanangkan oleh UNESCO yaitu Learning to know, learning to do, learning to be dan learning to live together(Zhao, n.d., p. 2). Kolaborasi pilar pendidikan UNESCO dan sekolah ini dapat terwujud dalam proses pendidikan yang dilakukan. Misalnya dalam mempelajari tentang pilar pangan, learning to know dilakukan dengan mengajak warga belajar untuk mencari tahu, dan menggali pengalaman tentang satu jenis makanan tertentu. Learning to do, dilakukan dengan mengajak anak-anak praktik secara langsung dalam pembuatan satu jenis makanan tertentu. Learning to be, dilakukan dalam ragka pengolahan bakat warga belajar yang intinya pengembangan soft skill dari anak-anak. Dengan praktik membuat makanan secara tidak langsung mengasah motorik halus dan motorik kasar melalui kegiatan dalam memasak. Terakhir, learning to live together dilakukan dengan mengajari anak berbagi makanan yang telah dihasilkan dari proses memasak. Dengan 
belajar berbagi maka sekaligus menanamkan kesadaran bagianak bahwa mereka adalah bagian dari kelompok atau masyarakat yang harus berbagi, berkerjasama dan berkolaborasi

Disisi lain, dalam pilar di atas terdapat prinsip yang dikembangkan di SALAM. Prinsip tersebut ialah menciptakan kehidupan belajar yang merdeka dimana seluruh proses pendidikan dibangun atas dasar kebutuhan dan kesepakatan bersama seluruh warga belajar. sehingga dalam proses pembelajaran di SALAM tidak ada anak atau warga belajar yang merasa terpaks melakukan seuatu hal. Berkaitan dengan hal tersebut, Bascia \& Maton (2015:1) menyebutkan:

The schools are small, supporting personalized relationships among teachers and students, with teacher-driven curricular programs that are responsive to student interests. Curricular innovation is made possible because alternative schools are only loosely coupled with the rest of the public education system, but they still must comply with school system regulations.

Kutipan tersebut mendukung prinsip belajar di SALAM bahwa kurikulum di sekolah alternatif bisa dengan bebas dibentuk sesuai dengan kebutuhan siswa dan kesepakatan antara guru dan siswa. Hal ini menunjukkan bahwa kepentingan peserta didik untuk belajar menjadi landasan utama dalam melaksanakan proses pendidikan. Sehingga kurikulum dan pembinaan yang dilakukan benar-benar mewakili kebutuhan peserta didik.

\section{c. Pembinaan minat}

Seperti dikemukakan sebelumnya, bahwa karakter pendidikan alternatif ialah memperhatikan minat peserta didik. Pembinaan minat peserta didik di SALAM dilakukanmelalui kelas minat. Berikut merupakan jenis kelas minat yang ada di SALAM.
Tabel 2. Jadwal kelas minat

\begin{tabular}{l|ll}
\hline No & Hari & Nama Kegiatan \\
\hline 1 & Senin & Menari \\
2 & Senin & Perkusi \\
3 & Selasa & Badminton \\
4 & Rabu & Penulisan \\
5 & Kamis & Mengambar \\
6 & Kamis & Fotography \\
7 & Sabtu & Futsal \\
\hline
\end{tabular}

Sumber: Data Penelitian

Dari tabel di atas, dapat dikatakan bahwa sekolah ini menyediakan banyak kegiatan untuk pengembanan minat dan bakat bagi peserta didik. Kelas minat yang disediakan pun beragam dan mampu menampung semua minat yang muncul. Sejalan dengan hal tersebut, Davies, B. \& Davies (2011, p. 151) mengemukakan kunci untuk membangun hubungan dan jaringan dalam pengembangan bakat dan minat meliputi:

1) Kolaborasi informal dapat berupa sekolah yang bermitra dengan sekolah tetangga untuk mengembangkan jaringan pembelajaran profesional dan jaringan pengembangan bakat.

2) Pengembanganfederasi lunak di mana sekolah-sekolah mengadopsi kerangka kerja yang lebih strategis dan menyetujui kode praktik untuk bekerja lintas kelompok untuk mencapai tujuan yang disepakati. Namun, setiap sekolah tetap memiliki badan pengaturnya sendiri.

3) Struktur atau kemitraan formal dapat dibentuk yang dikenal sebagai federasi keras. Di sini, sebuah sekolah bermitra dengan sekolah tetangga atau sekolah tetangga dan memiliki satu badan pemerintahan dan sistem administrasi dan manajemen yang terintegrasi. Staf yang ditunjuk untuk satu sekolah mungkin memiliki peran dan tanggung jawab di beberapa sekolah. Dalam federasi yang sulit, promosi dan pengembangan dapat terjadi dalam kelompok sekolah dan pengalaman yang direncanakan dapat dilakukan di lebih dari satu sekolah. 
4) Di sektor sekunder, pendirian sekolah mini dalam kerangka sekolah yang lebih besar memfasilitasi proses pengembangan bakat dengan menciptakan peluang kepemimpinan yang luas bagi para pemimpin 'sekolah mini' dan pemimpin potensial.

5) Kerjasama di semua sekolah,yang menyediakan pendidikan untuk anak usia 318 tahun, di mana seorang pemimpin eksekutif mengawasi fase primer dan sekunder, dan juga dalam beberapa kasus penyediaan sekolah khusus, memberikan peluang bagi para pemimpin berbakat dan pemimpin potensial untuk mengambil tanggung jawab lebih awal dalam kepemimpinan mereka.

6) Bentuk organisasi keenam adalah di mana sponsor sekolah mendirikan sejumlah besar sekolah di bawah pendekatan 'merek' atau 'rantai' yang mereka buat. Ini didasarkan pada model tipe bisnis yang lebih banyak di mana organisasi sponsor dapat melihat pengembangan bakat terjadi di berbagai cabang atau sekolah dalam grup.

Urian di atas menunjukkan ada beberapa hal yang bisa dilakukan sekolah untuk bersama-sama dengan sekolah lain mengembangkan minat siswanya. Kerjasama atau kolaborasi antar sekolah tersebut dapat terjadi baik secara informal, saling mengadopsi kerangka kerja, bermitra dengan seklah tetangga secara lebih luas, dan membuka cabang sekolah. Cara-cara tersebut bisa dipilih dan disesuaikan dengan lembaga yang diinginkan.

\section{d. Pembinaan peserta didik melalui forum orang tua.}

Forum orang tua merupakan sarana komunikasi antar orang tua, guru dan penyelenggara sekolah untuk memperoleh pemahaman bersama tentang proses belajar yang dilakukan oleh anak-anak. Forum orang tua juga menjadi sarana tukar pengalaan masing-masing orang tua serta guru terkait dengan perkembangan anak serta keterlibatan orang tua dalam proses belajar mengajar baik di sekolah maupun di rumahnya masing-masing. Hal tersebut menunjukkan bahawa pembinaan terhadap siswa bukan hanya menjadi tanggung jawab guru semata, namun juga mejadi tanggung jawab dari orang tua. Sinergi antara keduanya menjadi alat yang pas untuk menumbuh kembangkan anak.

Sinergi antara orang tua dan sekolah menjadi alat yang pas untuk menumbuhkembangkan anak. Hal ini karena sekolah ini merupakan komunitas belajar baik bagi orang tua maupun anak-anaknya. Sebagai komunitas, Starratt (2003, p. 183) mengungkapkan:

... good communities are made up of good individuals, strong communities of strong individuals, innovative communities of innovative individuals, caring communities of caring individuals, and self-governing communities of self-governing individuals. We assume that schools as communities are made up of both adults and students.

Kutipan tersebut secara tersirat mengungkapkan bahwa sebuah komunitas yang baik dibangun atas individu-individu yang baik, inovasi, kepedulian dan pengelolaan dalam komunitas tergantung pada apa ang dilakukan individu dalam komunitas itu. Dalam kaitanya dengan sekolah, maka individu dalam komunias ialah peseta didik, para guru dan orang tua.

Lebih lanjut Marini (2014, p. 93) menyatakan terdapat enam kategori keterlibatan orang tua dan masayarakat dalam pendidikan anaknya yaitu meliputi: pengsuhan anak, berkomunikasi, melakukan pekerjaan dengan sukarela, belajar di rumah, pembuatan keputusan, dan berkolaborasi dengan masyarakat. Disisi lain Starratt (2003, p. 184), juga mengungkapkan:

Empowerment is a term frequently used in discussions of school reform, 
especially discussions that focus on increasing the professionalism of teachers. Empowerment as a strategic tool of school reform, however, is not the panacea that many initially expected. Those who would place teachers in charge of schools have discovered that the principals and other administrators do not simply fall over and surrender their positions.

Dari kutipan tersebut maka dapat dikatakan bahwa sebuah komunitas memerlukan pendayagunaan yang bermanfaat dalam meningkatkan kualitas profesional guru. Sehingga pemberdayaan dapa menjadi alat untuk reformasi pendidikan di sekolah. Dalam konteks SALAM, pemberdayaan orang tua dalam pembinaan terhadap siswanya dapat mempermudah pencapaian tujuan pendidikan secara bersama-sama baik warga belajar, guru dan orang tua. Hal ini karena sekolah yang terisolasi dari orang tua dan masyarakat memiliki konsekuensi yang signifikan terhadap perilaku perkembangan anak-anaknya Marini (2014, p. 93)

\section{Evaluasi peserta didik}

Evaluasi terhadap peserta didik dilakukan setiap saat, namun pelaksanaannya berbeda antar masing-masing anak. Hal ini karena metode pembelajaran yang digunakan ialah metode riset. Sehingga evaluasi yang dilakukan terkait riset masing-masing anak, dan setiap anak memiliki waktu berbeda dalam melakukan riset. Dalam melakukanevaluasi setiap anak melakukan presentasi tentang risetnya, kemudian guru dan teman-teman sekelas memberikan pertanyaan atau masukan. Hal ini sesuai dengan petikan wawancara dengan Y berikut:

"kalau evaluasi di sini tentu berbeda dengan sekolah umumnya, disini evaluasi terkait riset yang dilakukan oleh anak-anak. Setiap anak mempresentasikan hasil risetnya, disitu ada evaluasi, tanya jawab dan masukan baik dari teman-teman sekelas dan guru pendamping".

Selain evaluasi terkait riset yang dilakukan oleh anak-anak, guru juga melakukan pencatatan terhadap perkembangan anak. Hasil catatan itulah yang nantinya akan dilaporkan kepada orang tua.

Metode evaluasi yang berbeda tentu juga menghasilkan penilaian yang berbeda. Sehingga setiap anak di sekolah ini selalu naik kelas. Karena fasilitator di SALAM memandang anak itu berbeda dan mereka mempunyai kecenderungan terhadap kecerdasan masing-masing. Sehingga dapat dikatakan semua anak dianggap cerdas dengan masing-masing keunikanya. Tidak ada tes yang diberikan kepada anak seperti pada sekolah pada umumnya untuk kenaikan kelas.

Disamping tidak ada tes untuk kenaikan kelas, peserta didik di sini juga melakukan UN. UN dilakukan sesuai dengan keinginan masingmasing anak-anak. Sebelum pelaksanaan UN anak-anak melakukan riset sendiri terkait soal UN nya. Selain itu anak-anak juga melakukan riset tentang tujuanya. Misal mereka ingin setelah dari sekolah ini masuk ke SMP 5 maka siswa melakukan riset tentang bagaimana persyaratan diterima di SMP 5 itu, apa yang harus dipersiapkan, termasuk mereka menyiapkan berapa nilai UN yang harus mereka peroleh untuk bisa diterima di sana. Sedangkan persiapan yang dilakukan untuk menghadapi UN ialah semua warga belajar melakukan riset terhadap soal-soal UN.

Berbeda dengan uraian sebelumnya Daryanto dan Farid (2013:58) mengemukakan evaluasi peserta didik dilakukan melalui penilaian hasil belajar yang bertujuan untuk melihat kemajuan belajar peserta didik terkait penguasaan materi pengajaran yang telah dipelajari.

Uraian di atas meunjukkan bahwa evaluasi yang dilakukan SALAM kepada peserta didiknya berbeda dengan evaluasi yang dilakukan oleh sekolah pada umumnya. 
Berkaitan dengan penilaian pembelajaran yang dilakukan sekolah pada umumnya, Basir (2015, p. 89) mengemukakan penilaian pembelajaran dilakukan dengan penilaian berbasis kelas dan penilaian berbasis portofolio. Jika dikaitkan dengan dua bentuk penialaian tersebut, maka penilaian yang dilakukan di sekolah ini lebih pada penilaian portofolio. Penilaian portofolio yaitu suatu model penilaian yang dilakukan secara sistematis dan logis untuk mengungkapkan dan menilai peserta didik secara komprehensif, objektif, akurat dan sesuai dengan bukti-bukti autentik (dokumen) yang dimiliki peserta didik (Basir, 2015, p. 115). Hal tersebut sesuai, mengingat penialain pembelajaran yang dilakukan di SALAM, antar anak berbeda satu sama lain disesuaikan dengan jenis riset yang dilakukan masing-masing. Selain itu, instrumen penilaiannya pun berupa hasil dan dokumen riset yang dimiliki oleh masing-masing anak.

Setelah evaluasi dilakukan, guru melakukan pelaporan kepada orang tua, berdasarkan studi dokumen diketahui bahwa dalam melakukan pelaporan ada tiga bentuk yaitu:

a) Catatan proses belajar anak berdasarkan riset satu semester.

Catatan berisi data-data siswa terkait dengan ketertertarikan, keaktifan, konsistensi, respons, kreativitas, inisiatif, ekspresi, dan ketekunan selama mengikuti proses riset yang terbagi dalam empat tahapan riset yaitu tahap perencanaan, tahap proses pencarian data, tahap olah data, dan tahap workshop. Pada tahapan olah data ditambahkan aspek pemahaman dan kemampuan siswa pada saat melakukan pengolahan data.Padatahapan workshop ditambahkan aspek ketuntasan, kecepatan, ketelitian, dan kecenderungan dalam menyelesaikan tugas.

b) Catatan sikap siswa selama proses belajar satu semester.

Catatan berisi data-data siswa terkait dengan sikap anak selama mengikuti proses belajar. Aspek yang dicatat meliputi: performance, solidaritas, empati, kerjasama, dan tanggungjawab.

c) Catatan kemampuan olah tubuh siswa selama mengikuti proses belajar satu semester

Catatan berisi data-data siswa terkait dengan kemampuan siswa dalam hal mengolah tubuhnya selama mengikuti proses belajar. Aspek yang dicatat meliputi: gerak motorik kasar dan gerak motorik halus.

Ketiga bentuk pelaporan siswa tersebut tentu berbeda dengan sekolah pada umumnya. Sekolah pada umumnya mengacu pada permendikbud No. 104 tahun 2014 yang menyatakan laporan hasil belajar merupakan hasil pengolahan nilai yang diperoleh dari tes, isinya berupa angka-angka dan deskripsinya. Dengan demikian dapat dikatakan sekolah pada umumnya lebih menekankan aspek pencapaian akademis dibandingkan aspek lainya. Sementara di SALAM, yang lebih menekankan pada proses pembelajaran riset raport lebih berpentuk deskripsi ketimbang angka.

\section{SIMPULAN DAN SARAN}

\section{Simpulan}

Uraian pada bab-bab sebelumnya membawa kesimpulan bahwa:

1. Pada proses penerimaan warga belajar, sekolah ini banyak dibantu oleh media untuk memasarkan sekolah. Disisi lain akuntabilitas proses pendidikan yang dilakukan oleh sekolah ini menjadi hal pokok yang membuat para orang tua percaya dan berpartisipasi dalam pendidikan yang diselenggarakan. Dalam proses seleksi penerimaan siswa pun akuntabilitas dan kesepemahaman orang tua dan pengelola menjadi kunci mutlak dan syarat anaknya diterima menjadi warga belajar, bukan pada aspek akademik.

2. Berkaitan dengan proses penempatan dan pembinaan peserta didik, yaitu:

a. Penempatan warga belajar disesuaikan dengan usia dan jenjang pendidikan yang tersedia. Jumlah siswa tiap kelas hanya 15 
orang tentu berbeda dengan jumlah minimaldan maksimal di sekolah pada umumnya.

b. Pembinaan akademik dan non akademik di sekolah ini mendasarkan pada empat pilar pendidikan yang meliputi pangan, kesehatan, lingkungan dan sosial-budaya. Dalam pelaksanaanya sekolah ini juga mempraktikkan empat pilar pendidikan UNESCO yaitu Learning to know, learning to do, learning to be dan learning to live together.

c. Pembinaan bakat dan potensi warga belajar di sekolah ini dilakukan melalui kelas minat. Kelas minat yang disediakan meliputi menari, perkusi, badminton, penulisan, menggambar, fotografi, dan futsal.

d. Pembinaan melalui forum orang tua merupakan sarana pemberdayaan dan melibatkan partisipasi dari orang tua untuk pendidikan anaknya dalam rangka mencapai tujuan pendidikan bersama.

3. Evaluasi terhadap peserta didik dilakukan setiap saat, namun pelaksanaannya berbeda antar masing-masing anak. Hal ini karena metode pembelajaran yang digunakan ialah metode riset. Sedangkan untuk pelaporan hasil belajar siswa, sekolah ini membagi raport menjadi tiga bagian yaitu catatan proses belajar anak berdasarkan riset satu semester, catatan sikap selama proses belajar satu semester, dan catatan kemampuan olah tubuh siswa selama mengikuti broses belajar satu semester.

\section{Saran}

Dari kesimpulan di atas, saran yang peneliti berikan kepada pengelola SALAM untuk meningkatkan efektivitas manajemen. Selanjutnya rekomendasi untuk praktisi pendidikan agar belajar dari sekolah ini untuk mengaplikasikan metode riset dalam pembelajaran yang menggunakan kurikulum 2013.

\section{DAFTAR PUSTAKA}

Basir, M. (2015). Evaluasi Pendidikan. Sengkang: Lampena Intimedia.

Davies, B. \& Davies, B. . (2011). Talent management in education. London: Sage Publications Ltd.

Farikhah, S. (2015). Manajemen lembaga pendidikan. Yogyakarta: Aswaja.

Halimah, S. (2018). Pelaksanaan pembelajaran di sekolah kehidupan sanggar anak alam (SALAM) yogyakarta. Universitas Negeri Yogyakarta.

Hamiyah, N. \& Jauhar, M. (2015). Pengantar manajemen pendidikan di sekolah. JakartaPrestasi Pustakaraya.

Imron, A. (2011). Manajemen Peserta Didik Berbasis Sekolah. Jakarta: Bumi Aksara.

Ismail, M. (2016). Homeshooling: sebuah pendidikan alternatif. Lentera Pendidikan, 19(1), 100-111.

Kristiawan, M., Safitri, D. \& Lestari, R. (2017). Manajemen pendidikan. Yogykarta: Penerbit Deepublish.

Marini, A. (2014). Manajemen sekolah dasar. Bandung: PT Remaja Rosdakarya.

Maxwell,J.A. (2013). Qualitative research design an interactive approach. Los Angeles, London, New Delhi, Singapore, Washington DC: Sage Publication

Miarso, Y. (2000). Pendidikan Alternatif Sebuah Agenda Reformasi. Retrieved from http://sumberbelajar.belajar.kemdikbud .go.id.pdf

Rahardjo, T. (2018). Sekolah biasa saja. Yogyakarta: Insist Press

Solihat, E. \& Sugiharto, T. (2009). Pengaruh transparansi dan akuntabilitas 
Manajemen Peserta Didik di PKBM Berbasis Alam Studi pada Sanggar Anak Alam (SALAM) | Gunarti I. Pradewi, dkk.

pengelolaan Pendidikan terhadap partisipasi orangtua murid di sma negeri 107 jakarta. Jurnal Ekonomi Bisnis, 14(2).

Starratt, R. J. (2003). Centering educational administration cultivating meaning, community, responsibility. New Jersey And London: Lawrence Erlbaum Associates, Inc., Publishers.

Sugiyono. (2013). Metode Penelitian Pendidikan Pendekatan Kuantitatif, Kualitatifdan $R \& \quad D$. Bandung: Alfabeta.

Sulistyaningsih. (2017). Implementasi model pengelompokan pesera didik dalam kelas paralel di SD Muhammadiyah 8 Jagalan Kelas V tahun ajaran 2016/2017. Publikasi Ilmiah. Retrieved from

http://eprints.ums.ac.id/51238/1/Artikel

Publikasi Publikasi.pdf
Trihantoyo, S. (2015). Manajemen sekolah dasar berbasis akuntabilitas kinerja. Jurnal Widyagogik, 3(1). Retrieved from

http://eprints.ums.ac.id/51238/1/Artikel Publikasi Publikasi.pdf

Wildensyah. (2016). Sebuah alasan memilih pendidikan alternatif. Good News from Indonesia. Retrieved from https://www.goodnewsfromindonesia.i d/2016/12/29/sebuah-alasan-memilihpendidikan-alternatif

Zhao, Z. N. (T. T. (n.d.). Four 'Pillars of Learning' for the Reorientation and Reorganization of Curriculum: Reflections and Discussions. Retrieved from http://www.ibe.unesco.org/cops/Compe tencies/PillarsLearningZhou.pdf. 